\title{
Lumen
}

Selected Proceedings from the Canadian Society for Eighteenth-Century Studies

\section{Appeals to Antiquity: Reflections on some French Enlightenment Readings of Socrates and Plato}

\section{Sophie Bourgault}

Volume 29, 2010

URI : https://id.erudit.org/iderudit/1012025ar

DOI : https://doi.org/10.7202/1012025ar

Aller au sommaire du numéro

Éditeur(s)

Canadian Society for Eighteenth-Century Studies / Société canadienne d'étude du dix-huitième siècle

ISSN

1209-3696 (imprimé)

1927-8284 (numérique)

Découvrir la revue

Citer cet article

Bourgault, S. (2010). Appeals to Antiquity: Reflections on some French

Enlightenment Readings of Socrates and Plato. Lumen, 29, 43-58.

https://doi.org/10.7202/1012025ar

Copyright (c) Canadian Society for Eighteenth-Century Studies / Sociéte canadienne d'étude du dix-huitième siècle, 2010
Ce document est protégé par la loi sur le droit d'auteur. L'utilisation des services d'Érudit (y compris la reproduction) est assujettie à sa politique d'utilisation que vous pouvez consulter en ligne.

https://apropos.erudit.org/fr/usagers/politique-dutilisation/ 


\section{Appeals to Antiquity: Reflections on some French Enlightenment Readings of Socrates and Plato}

In his study of the Enlightenment, Peter Gay writes that the philosophes' "shabby" treatment of Plato "has long perplexed and annoyed students of the eighteenth century." ${ }^{11}$ Many philosophes would have agreed with Thomas Jefferson's description of the Republic as the "whimsies, the puerilities, and unintelligible jargon" of a "foggy mind". ${ }^{2}$ On the whole, it seems fair to characterize the French Enlightenment as an anti-platonic moment in the history of ideas. ${ }^{3}$ What is remarkable is the fact that the philosophes could, in the same breath, hail Socrates as their friend and dismiss Plato as their foe. If Plato was the object of intense scorn, Socrates was the object of equally intense admiration. If Plato was dismissed for his obscurity and hubris, Socrates was celebrated for his courageous death and his battle against superstition and fanaticism. ${ }^{4}$ Embracing Socrates and objecting to Plato presupposes that one can draw a clear line between them - a dubious premise, but one that is not unique to the $18^{\text {th }}$ century. Dana Villa recently argued

1 Peter Gay, The Enlightenment: An Interpretation. vol.1 (New York: Random House, 1968), 82.

2 The Complete Jefferson (New York: Tudor, 1943), 1034-35.

3 This is not to deny that there were some Platonists in the $18^{\text {th }}$ century. But what matters for us here is that self-avowed Platonists were not the norm in France, and more importantly, that most philosophes did not see themselves as Platonists.

4 There were, of course, other Socrateses - including Christian ones. See Ian Macgregor Morris, "The Refutation of democracy? Socrates in the Enlightenment," in Socrates from Antiquity to the Enlightenment, ed. M.B. Trapp (Aldershot: Ashgate, 2007). 
that Plato is a dogmatic elitist and the creator of a "tyranny of reason" whereas Socrates is a "kind of democrat" and the inventor of "the secular conscience. ${ }^{\prime 5}$ In other words: Plato is the friend of religious fanatics and conservatives, whereas Socrates is the friend of liberal atheists. It is not possible to offer here a sustained challenge to these overly dichotomic interpretations - whether those written two hundred years ago by some philosophes or ten years ago by scholars like Villa. My intention here is more modest: I want to start charting out this divide between the 'bad Plato' and the 'good Socrates' and to try to explain what lies behind it.

To put it most simply, my argument will be that the French philosophes put Socrates well above Plato because they preferred action to contemplation, critique to speculative philosophy - and they did so because they associated contemplation with Christian scholasticism and with fanaticism, obscurity and futility. This is not to claim, of course, that the philosophes did not care for 'philosophy', but only that they objected to a particular embodiment of it, which they wrongly associated with a man by the name of Plato. In many respects, I believe that our current anti-foundationalism is quite analogous to the French Enlightenment's anti-clericalism - and it may well be one of its legacies. Behind both lie a shared desire to vindicate 'political action' and a shared (if dubious) belief that this vindication necessarily calls for a rejection of speculative contemplation. The presumption of this essay, therefore, is that studying the French Enlightenment's relationship to Platonism can tell us something about ourselves.

In our discussion, Jean-Jacques Rousseau's case will prove most instructive, in part because it was so exceptional. Contra Diderot and Voltaire, Rousseau loved Plato and became increasingly critical of Socrates as he aged. Faced with that exception, the temptation is great to simply categorize Rousseau as a counter-Enlightenment figure. But this paper will argue the very opposite: I will use Rousseau's treatment of Socrates and Plato as a way to show Rousseau's affinities with the French Enlightenment - particularly with its dogmatic prejudice against speculative philosophy. Although Rousseau seems to be at odds with Diderot and Voltaire in his overturning of their own ranking of Socrates and Plato, the main reasons behind Rousseau's inversion are quite consistent with the general spirit of les lumières.

After presenting what I take to be a fairly 'standard' French Enlightenment reading of Socrates and Plato - that of Diderot and Voltaire 
- the paper turns to Rousseau's own peculiar treatment. What I show is that Rousseau repeats the same problematic move made by the philosophes: that of elevating 'action' at the expense of 'contemplation' and that of separating what Plato saw as united: the sky and the city.

\section{The heroism of citoyen Socrates and the chimeras of (the not-so-divine) Plato}

The Eighteenth century was certainly not the first one to care deeply about Socrates: ever since his death, Socrates had been the object of much praise - and, in some rare cases, of much criticism. And yet, there was something unprecedented about the intensity of the philosophes craze for Socrates - a craze which was largely rooted in their self-identification with the persecuted philosopher. Indeed, an analogy was often drawn between modern Paris and ancient Athens. Speaking for many, Condorcet wrote, in his Esquisse d'un tableau historique, that Socrates' death was "le premier crime qui ait signalé cette guerre de la philosophie et de la superstition qui dure encore parmi nous." Condorcet was convinced that this war would last "tant qu'il restera sur la terre des prêtres ou des rois." ${ }^{\prime 6}$ As such, it is hardly surprising that the 'cult' surrounding Socrates was only invigorated by the various attempts to censor the Encyclopédie and to persecute its authors.

Thus, many philosophes saw Socrates' death as a powerful symbol for their own fight against intolerance and the authorities appeared to have found the philosophes' Socratic self-identification threatening: Sauvigny's play La mort de Socrate was taken off the stage in 1762, and the parallels often drawn between the philosophes and Socrates were regarded at once as flattering and dangerous. ${ }^{7}$ If there was quasi-unanimity about the meaning of Socrates' death amongst the philosophes, there was, however, less consensus around what to do with Socrates' life - i.e. with his deeds and words. Although Voltaire tried to flatter Frederick by comparing him to Socrates, he clearly indicated to his patron the limits of his appreciation for the ideas of the Greek philosopher: "je déteste les persécuteurs de Socrate, sans me soucier infiniment de ce sage au nez épaté. ${ }^{8}$ Voltaire repeatedly characterized Socrates as

6 Esquisse d'un tableau historique (Paris: Flammarion, 1988), 127-28.

7 For a detailed discussion, see Raymond Trousson, Socrate devant Voltaire, Diderot et Rousseau (Paris: Minard, 1967), 78.

8 Letter of Feb. 20. 1737, cited in Trousson, Socrate, 42. 
"niais" (his lack of 'street-smarts' evidenced by his inability to save his own skin) and as being unbearably antisocial. ${ }^{9}$ But what the seigneur de Ferney was certainly willing to celebrate is Socrates' courageous battle against superstition and his sincere love for morality. ${ }^{10}$

If Voltaire was only mildly interested in the moral teachings of Socrates, Diderot was exceedingly so. Specifically, what earned Diderot's respect was that Socrates not only 'theorized' virtue, but most importantly, that he lived it, that he put it into action. His philosophy " $n$ 'étoit pas une affaire d'ostentation et de parade, mais de courage et de pratique." ${ }^{11}$ Diderot's admiration for the 'man of action' Socrates started early, and it was strengthened by his stay at Vincennes - where he translated Plato's Apology into French and where he experienced first hand what it could mean to be willing to die for the cause of philosophy (he, in fact, realized that he did not have what it took to be a martyr). Diderot soon thought of writing a play on Socrates' death - "une sorte de drame où l'on présenterait la morale directement et avec succès." ${ }^{12}$ Although the play was never actually written, Diderot envisioned it as a way of teaching French men about virtue.

A year later, Voltaire picked up on Diderot's idea and wrote a comedy about Socrates. Contra Diderot, Voltaire's Socrate did not intend to teach people how to live well, but rather, to teach a few lessons to intolerant priests. As Voltaire wrote in a letter: "Puisse cet ouvrage faire trembler les fanatiques. ${ }^{13}$ Never one to be afraid of anachronism (especially if it serves the cause of anticlericalism), Voltaire presents us with a Socrates put on trial above all for his deism. ${ }^{14}$ Painting priests in a particularly unfavorable light, the play was, at base, a manifesto for anticlericalism. ${ }^{15}$ Voltaire's strategic appeal to the example of Socrates

9 Socrate, Ouvrage dramatique en trois actes, in Oeuvres complètes de Voltaire (Paris: Garnier, 1877), vol. 5. (Hereafter OC)

10 Voltaire, Dictionnaire Philosophique, in OC vol. 20, 428-30.

11 Lettre de Raynal à Grimm, in Diderot, CEuvres, L. Versini éd. (Paris: Laffont, 19941997), vol. III, 774.

12 De la poésie dramatique, in Diderot, CEuvres, vol. IV, 1284-85; 1339-41.

13 Lettre à Cramer, Juillet 1759, cited in Trousson, 34. See also Russell Goulburn, "Voltaire's Socrate", in Socrates from Antiquity to the Enlightenment, ed. M.B. Trapp (Aldershot: Ashgate, 2007).

14 Voltaire, Socrate, in OC vol. 5.

15 Goulburn nevertheless cautions us against reading it simply as 'pro-philosophe propaganda' — see his excellent "Voltaire's Socrate," 241-43. 
in the Traité de la tolérance had a similar motivation: to score points against Christians, he argued that relative to their own fanaticism, that of democratic Athens was negligible. "L'exemple de Socrate est au fond", Voltaire wrote, "le plus terrible argument qu'on puisse alléguer contre l'intolérance." ${ }^{\prime 16}$ Perhaps only a Voltaire could use the example of Socrates to support at once two contradictory theses: that Socrates was the victim of intolerance, and yet, that Ancient Athens was not inherently intolerant.

If Voltaire's admiration for Socrates was an intricate and fluctuating affair, Diderot's was not. His love for the son of Sophronisque was unwavering - and so was his dismissal of Plato. Quite revealing of Diderot's treatment of Socrates and Plato are the two Encyclopédie articles he dedicated to them. In the very Ciceronian entry 'Socratique', the bulk of Diderot's praise for Socrates was tied to considerations of utility and action (two central Enlightenment concerns - wasn't the true philosophe described by Dumarsais' famous entry as "un honnête homme qui veut plaire et se rendre utile"?). Indeed, Diderot celebrates Plato's mentor for his "esprit porté aux choses importantes et d'une utilité générale et première." Contrary to his student who got his head caught up in the sky, Socrates

vit qu'il falloit travailler pour rendre les hommes bons, avant de commencer à les rendre savans; que tandis qu'on avoit les yeux attachés aux astres, on ignoroit ce qui se passoit à ses piés... que le tems se perdoit en spéculations frivoles... et il ramena sur la terre la philosophie égarée dans les régions du soleil. $^{17}$

Diderot commended Socrates for taking men out of obscurity and for turning them into good citizens. Significantly, Diderot turned a blind eye to the Socratic retreat from politics and instead, described Socrates as an exemplary yet perfectly modest citizen. Finally, the article 'Socratisme' could not fail to mention with admiration the philosopher's healthy skepticism and admirable defense of freedom of thought in a hostile city.

While not being aggressive or completely dismissive in tone, Diderot's article 'Platonisme' nevertheless emphasized the overly speculative, dogmatic and unintelligible character of Platonic philosophy.

17 Art. 'Socratique', in Encyclopédie ou Dictionnaire raisonné des sciences, des arts et des métiers (Compact Edition, Pergamon Press), vol. III, 552. 
Unlike the modest and negative teaching of Socrates (i.e. he knew that he knew nothing), Platonism is compared to "une religion que les hommes professerent depuis son établissement, sans interruption, jusqu'à ces derniers tems." ${ }^{18}$ Also, relative to his student Aristotle, who 'examined, divided, distinguished and disputed,' Plato "semble prophétiser" (it is far from clear that this was a compliment). Although Diderot was generous enough to concede that there was, at times, some healthy skepticism in Plato, he nevertheless faulted him for his hubris and obscurantism: "[i]l tenta de remonter à l'origine des choses et il se perdit dans ses spéculations." Not surprisingly then, Plato "est souvent obscur."

The charges of obscurity, futility and epistemological hubris were perhaps the most common charges made against Plato during the French Enlightenment - to the point that they seem to have acquired the status of dogmatic clichés (and for an age so critical of doctrinarian thinking, the Enlightenment was remarkably blind to its own). In his Système de la Nature for instance, D'Holbach refers to Plato as "ce créateur de chimères" who had 'heated brains', a 'decided taste for the marvelous' and whose philosophy was synonymous with fanaticism. ${ }^{19}$ Helvétius' De l'Esprit repeatedly derides the "chimère platonicienne" and the inintelligibility of Platonic virtue. ${ }^{20}$ Montesquieu's verdict is also merciless: Plato's dialogues are insupportable and rest on false philosophy. ${ }^{21}$

Voltaire is thus in fine company when he reproaches Plato for his inintelligibility and 'galimathias', and when he mockingly suggests that the philosopher ought to have taken writing lessons (if not philosophy lessons) from John Locke. Contrary to the faithful reader of the Essay on Human Understanding, "un homme qui saurait tout Platon, et qui ne saurait que Platon, saurait peu, et saurait mal."22 Similar charges abound in Diderot's work. In his Apologie de l'abbé de Prades (a eulogy for religious tolerance and empiricism), Diderot denounced the epistemological "chimère de Platon" - i.e. the belief in innate ideas. ${ }^{23}$

Art. 'Platonisme', Encyclopédie, vol. II, 1427 (emphasis mine).

19 Système de la nature, vol. II (Hildesheim: Georg Olms, 1966), 79-80 \& vol. I, 115.

20 De l'Esprit, in CEuvres Complètes (Hildesheim: Georg Olms, 1967), vol. III, 143; vol. II, $185-88$.

21 Essai sur le goût, ed. Charles-Jacques Beyer (Geneva: Droz, 1967), 61.

22 Siècle de Louis XIV, in OC vol. 14, 562. See also Essai sur les mœurs, in OC vol. 11, 77. 
Moreover, despite being genuinely interested in music (he wrote all Encyclopédie articles on music instruments and a treatise on music pedagogy), Diderot had no patience for the musical metaphysics of Plato - which he described as "d'une obscurité impénétrable." ${ }^{24}$ It is thus hardly surprising that in his Plan d'une université, he admitted to Catherine that "les ouvrages de Platon... sont trop profonds, même pour les maitres." ${ }^{25}$ More generally, Diderot associated the name of Plato with a dogmatic 'esprit de système' - the great bugbear of the philosophes. And it was on that very basis that Diderot lodged the curious charge against Helvétius that the latter was too much of a Platonist. What Diderot meant was that Helvétius sought to create a new system and of being as abstract and dogmatic about it as Plato was. ${ }^{26}$ Quite remarkably, the Encyclopédie article 'Philosophie' sees in the 'esprit de système' and in the excessive authority given to ancient philosophers like Plato, two key obstacles to good philosophy. The "préjugés ridicules que nous avons pris en faveur des anciens" ought to be questioned; the label of 'divin' attached to the name of Plato ought to be discarded. Plato is all-too-human - and, as Voltaire enjoyed noting, the last decades in philosophy have done a lot more for the human race than all the works of previous ages. ${ }^{27}$

Of course, in light of their strong empiricism, it is hardly surprising that many French philosophes should have had little patience for Platonic metaphysics. But the vehemence with which they rejected Plato is still suspect, as is the hostility with which they labeled him as "inintelligible." While not denying the complexity of Platonic dialogues (or the theory of the Forms), it seems a little odd that such a large group of gens de lettres would suddenly be unable to understand the Platonic corpus. And this is particularly puzzling in light of the recurrent compliment paid to Plato by the likes of Diderot and Voltaire: that of eloquence. Indeed, if Plato's work was widely dismissed as 'bad philosophy', it was nevertheless often applauded for its literary value. Voltaire repeatedly praised Plato for his beautiful "roman de l'âme" and eloquence, ${ }^{28}$ and Diderot conceded that "il est peut-etre moins à lire pour les choses 
qu'il dit que pour la manière de le dire. ${ }^{\prime 29}$ Of course, the separation between eloquence and truth is an old one - and in fact, it is already expressed in Plato's Republic. The irony, of course, is that Diderot and Voltaire put Plato squarely on the side of sophistry - against that of philosophy.

It seems that Plato was the target of the French Enlightenment's anticlericalism. With his name were associated the vices of Christian thought: obscurity, uselessness and hubristic metaphysics. D'Holbach's Système de la nature captures this quite well:

Platon, ce grand créateur de chimères, dit que ceux qui n'admettent que ce qu'ils peuvent voir et manier sont des stupides et des ignorants qui refusent d'admettre la réalité de l'existence des choses invisibles. Nos théologiens nous tiennent le même langage : nos religions européennes ont été visiblement infectées des rêveries platoniciennes... si la philosophie consiste dans la connaissance de la nature, l'on sera forcé de convenir que la doctrine platonique ne mérite aucunement ce nom, vu qu'elle n'a fait qu'écarter l'esprit humain de la nature visible pour le jeter dans un monde intellectuel, où il ne trouva que des chimères. ${ }^{30}$

What was also associated with the name of Plato and scholasticism was an understanding of the contemplative life as reclusive and solely directed towards the otherworldly. If Socrates was particularly attractive to men like Diderot, it was because he did not live an isolated contemplative life - instead, he fitted quite well the job description provided by the Encyclopédie's article 'Philosophe': "ses besoins et le bien être l'engagent à vivre en société ... Notre philosophe ne se croit pas en exil dans ce monde; il ne croit point être en pays ennemi. ${ }^{\prime \prime 1}$ Unduly associated with a eulogy of seclusion, Plato is discarded without being given the chance for a fair trial - a trial that could have shown the extent to which his philosophy begins and ends in the city. Put differently, my claim (which I cannot unfortunately defend here) is that Plato's philosopher could have met the job description cited above. After all, even in his most 'metaphysical' task (dialectical inquiry), the philosopher is sociable and concerned with political tasks - most notably, that of teaching.

29 Art. 'Platonisme', Encyclopédie, vol. II, 1427.

30 Système de la Nature, vol. II, 79-80.

31 Encyclopédie, vol. II, 1368. 
In her study of the Enlightenment's treatment of antiquity, Chantal Grell observes that Platonic dialogues were not widely available in the $18^{\text {th }}$ century and that Plato was 'remarkably absent' from the collèges' curriculum. ${ }^{32}$ Thus, it may be tempting to conclude that the philosophes' 'prejudiced' treatment of Plato was the result of ignorance. The claim would be that the philosophes could not appreciate Plato's insights on government or education simply because they were insufficiently aware of the 'political' and 'modest' Plato, and overly aware of the 'metaphysical' and hubristic Plato of Christian thinkers. But such a hasty conclusion would be weak for many reasons. One is that some Enlightenment thinkers did pay attention to Plato's political insights most notably, Rousseau. It was therefore a conscious choice on Diderot and Voltaire's part not to read or at least, not to discuss at length, Plato's Republic or Laws - and it was also a conscious choice to brood over the difficult metaphysics of the Timaeus or the Republic while overlooking the latter's political teachings. These were choices that are full of significance, and they are choices that remain meaningful to this day. As we will now see, Rousseau made a different choice. Jean-Jacques read Plato for his political insights and became increasingly convinced that Socrates was less worthy of our time than his student.

\section{Rousseau re-interprets Socratism and Platonism with an Enlightenment lens}

Rousseau's infatuation with Socrates is well known: thanks to Clifford Orwin and Raymond Trousson, we are familiar with the peculiarities and intensity of Rousseau's Socratism. I thus have no intention of going over the minute details of that infatuation here - I merely wish to indicate its general spirit and its qualified nature.

Rousseau's relationship with Socrates has typically been described as one which began in an intense and unconditional worship - one clearly expressed in the Discours sur les Sciences et les Arts. Slowly, it is said, the worship eroded as Socrates became increasingly overshadowed by Cato and Jesus (if interpreters such as Orwin doubt the sincerity of Rousseau's attachment to Christ, Yves Touchefeu gives us evidence to the contrary). ${ }^{33}$ And then, finally, the 'Socratism' of Rous-

33 "Rousseau's Socratism" The Journal of Politics (60:1, 1998), 174. Touchefeu, L'Antiquité et le christianisme dans la pensée de Jean-Jacques Rousseau (Oxford: SVEC, vol. 372, 1999). 
seau is said to have reached an inevitable rupture point around 1762, when Rousseau finally discarded Socrates as a hero. ${ }^{34}$

What is remarkable about the first discourse's treatment of Socrates is that the old man is celebrated for his "éloge de l'ignorance" and is depicted as an 'anti-philosopher.' But, contra Leduc-Fayette, this depiction need not be seen as indicative of a 'counter-Enlightenment' stance in Rousseau. For one thing, the 'ignorance' Socrates advocates is not brutish stupidity but rather: "une ignorance raisonnable, qui consiste à borner sa curiosité à l'étenduë des facultés qu'on a reçuës; une ignorance modeste, qui nait d'un vif amour pour la vertu. ${ }^{\prime \prime 35}$ This praise of intellectual modesty is not unfamiliar: if the French Enlightenment can be largely described as an age of "philosophical modesty," ${ }^{36}$ Rousseau is quite in line with his age. While Rousseau's ignorance modeste is not perfectly analogous to the philosophes' epistemological modesty, his characterization of Socrates as no pedantic savant seems reminiscent of Diderot's own description of Socrates as the modest teacher of a merely negative doctrine.

In a revealing passage of the first discourse, the story of Socrates becomes fused with that of Cato: "[ce que] Socrate avoit commencé dans Athénes, le vieux Caton continua dans Rome...." ${ }^{\prime 37}$ Elsewhere, Rousseau also writes that Cato gave to mankind "le spectacle et le modele de la vertu la plus pure qui ait jamais existé." ${ }^{\prime 38}$ We see here that the Socrates of the 'young' Rousseau was already competing against Cato for the first prize in virtue. And, in fact, when compared to Jesus, Socrates is already inferior in moral excellence. ${ }^{39}$ What all this suggests is that Rousseau's early Socratism is not as boundless as suggested by the likes of Trousson, and that Rousseau's later 'turn against' Socrates may not be inconsistent with the first discourse.

Simply put, the main reason for Rousseau's later deprecation of Socrates is that Socrates failed to care enough for the city and be useful to it. ${ }^{40}$ This tying of virtue to dedication to the city is obviously not unique

Trousson, Socrate.

Rousseau, CEuvres Complètes (Paris: La Pléiade), vol. III, 54. (Hereafter ROC)

Gay, The Enlightenment, 143.

ROC III, 13

ROC III, 87

For example see ROC III, 47. On Jesus' humility, see ROC III, 45.

ROC IV, 626-27. For Jesus' heroism, see Fragment ou morceau allégorique sur la révélation. 
to Rousseau's later works. In his early Discours sur la vertu, Rousseau is already clear about the fact that Cato's actions are by far superior and more useful than all of Socrates' wisdom. More than that, Socrates is to be criticized for the egotistical nature of his intellectual concerns.

En effet, le soin de sa propre félicité fait toute l'occupation du Sage... Les vues du vrai Héros s'étendent plus loin ; le bonheur des hommes est son objet... Les Philosophes, je l'avoue, prétendent enseigner aux hommes l'art d'être heureux, et comme s'ils devoient s'attendre à former des nations de Sages, ils prêchent aux Peuples une félicité chimérique qu'ils n'ont pas eux-même et dont ceux-ci ne prennent jamais ni l'idée ni le goût. Socrates vit et déplora les malheurs de sa patrie; mais c'est à Trasibule qu'il étoit réservé de les finir. ${ }^{41}$

The parallel between Cato and Socrates will recur in Rousseau's Discours sur l'Economie Politique and Emile - in both instances for the purpose of showing that Socrates is not an appropriate role model for politics. ${ }^{42}$ Specifically, Socrates is accused in the Emile of being the type of Sçavant for which Rousseau has little patience: the self-centered, overly speculative and proud philosopher.

Contrary to the Socrateses of Diderot and Voltaire, that of Rousseau is repeatedly presented as a philosopher who only talks to "quelques particuliers" about virtue, instead of living it and stimulating emulation in others. ${ }^{43}$ Especially when compared to Christ, Socrates failed to shine. Rousseau became increasingly convinced that the parallel drawn between Socrates and Jesus was profoundly insulting to the latter: not only because Socrates' death was easy and comfortable compared to that of Christ, but also because, unlike Jesus, Socrates lacked humility (not only in his attire, but also in his approach to virtue). In the Fiction ou morceau allégorique sur la révélation (in many respects an anticlerical manifesto), Rousseau presents us with an allegorical discussion of the relative merit of three archetypes (listed here in order of increasing virtue): the philosophe, Socrates and Christ. Socrates is praised for unveiling the reality of superstition and priestly corruption, but he is also criticized for failing to fill in the void caused by critical philosophy

41 ROC I, 1263; emphasis mine. Rousseau also includes Plato in his list of 'wise' men who cannot compete against the greatness of men like Cato.

42 See also ROC III, 1896-99.

43 ROC III, 255; IV, 626. 
and for not going as far as Christ in the battle against superstition. ${ }^{44}$ Also, Socrates' manners and discursive method are deemed to be less 'popular' and modest than those of Christ. ${ }^{45}$ According to Rousseau, Jesus provides us with a much more politically useful model of virtue than Socrates: whereas the Socratic road to virtue was through reason and dialectic (both ineffective with the majority of men), Jesus's was through sentiment (the most accessible and politically pertinent tool of all). ${ }^{46}$

In short, most of Rousseau's objections to Socrates come down to the fact that the latter failed to care about what was useful to the city and that he showed rationalist hubris. ${ }^{47}$ This seems quite reminiscent of several of the objections voiced by Diderot and Voltaire against Plato. Yes, unlike many philosophes, Rousseau censured Socrates and put him well below Christ, but he did so largely for 'Enlightenment' concerns about epistemological modesty and political expediency. As we will now see, his embrace of the 'political' Plato was based on similar concerns.

The extent and nature of Rousseau's Platonism is a contentious (and insufficiently studied) matter: if Charles Hendel describes this Platonism as profound, Henri Gouhier speaks of it as 'périphérique' whereas, in a recent work, David Williams argues that Rousseau's "commitment to Platonism animates his entire belief system." ${ }^{48}$ Putting aside the Bible and Plutarch, references to Plato are the most recurrent ones in Rousseau's oeuvre. ${ }^{49}$ There seems to be little reason to doubt that Plato is near to Rousseau's heart and that the Republic, Laws and Statesman shaped his political thought. But I would disagree with the likes of Williams who claim that Rousseau's Platonism is profoundly epistemological and metaphysical. Indeed, as we shall see, Rousseau's praise for Plato, while sincere, was limited. And the limits of his Platonism were set by concerns that are fairly typical of the French Enlightenment.

44 ROC IV, 1053. More specifically, Socrates' crime is to have submitted to the (unjust) laws of Athens.

45 ROC IV, 1053.

46 ROC III, 156.

47 ROC II, 1263-74. Rousseau even accuses Socrates of sophistry in ROC IV, 1051-53.

48 Hendel, Jean-Jacques Rousseau moralist (London, 1934); Gouhier, Les Méditations métaphysiques de Jean-Jacques Rousseau (Paris, 1984); Williams, Rousseau's Platonic Enlightenment (University Park: Penn State Press, 2007), 88.

49 M. J. Silverthorne, "Rousseau's Plato" (S.V. 116, 1973), 235. 
The bulk of Rousseau's appreciation of Plato centers around the latter's care for the city. In the Contrat Social and the Discours sur l'économie politique for instance, Plato's authority and good judgment are repeatedly appealed to on the topic of law, the wise legislator, and punishment. In his second discourse, he also notes: "Combien est-il plus légitime de dire avec le sage Platon que la parfaite félicité d'un royaume est qu'un prince soit obéi de ses sujets, que le prince obéisse à la loi, et que la loi soit droite et toujours dirigée au bien public." ${ }^{\prime 50}$ Here and elsewhere, Plato is explicitly referred to and praised in his quality as a sage - a sage whose wisdom is geared towards utility and le bien public. But, as Zev Trachtenberg has noted, Rousseau's conception of the public good has little to do with Plato's Good (and this, in my view, is no minor detail):

in contrast with the transcendent knowledge of the forms that leads to the Platonic recognition of the common good, for Rousseau recognizing the common good requires what we can call 'immanent' knowledge: knowledge of specific facts about the individuals whose collective good is at issue, including facts about what these individuals themselves want. ${ }^{51}$

But Plato was for Rousseau more than simply an authority on law and lawgivers: he was also cited as an authority on pedagogical and cultural matters. While Rousseau willingly recognizes the limited utility of the Republic's public education system for his contemporaries, he nevertheless describes this Platonic dialogue as "le plus beau traité d'éducation qu'on ait jamais fait." ${ }^{152}$ Much credit is also given to Plato in the Lettre à d'Alembert for the sensible things Plato said regarding theater, poetry and censorship. ${ }^{53}$

Rousseau thus sees Platonic philosophy as one of 'action' - a philosophy concerned with useful and concrete political matters - and one that is, quite significantly, intelligible. If this reading of Plato seems to be much more balanced than that of Diderot and Voltaire's, it is in my view equally deficient. It is deficient (or incomplete) in that it puts aside a very significant part of the Plato's political vision: transcendence.

50 ROC III, 183. Also III, 249; 313, 381, 385, 412.

51 Trachtenberg, "Rousseau's Platonic Rejection of Politics", in Rousseau et les Anciens, R. Grant and P. Stewart eds. (Montréal: 2001), 187.

52 ROC IV, Emile, 250.

53 ROC III, 61, 106, 109; IV, 1009. 
Rousseau's writings on music are quite revealing of this 'incomplete' Plato. In his Dictionnaire de Musique for instance, Rousseau repeatedly cites Plato as 'the' authority on the close connection between music, the soul and politics. But, just like Diderot, Rousseau shows no interest in Plato's theoretical reflections on the science of harmony or in his idea of a music of the spheres. And, as his article 'Musique' for the Encyclopédie makes clear, this is not merely a case of indifference - it is, rather, a case of explicit disapproval. We know that Rousseau was in charge of writing most Encyclopédie entries on music, and that what served as the basis for his entries was Chambers' Cyclopedia. Now, it is informative to compare Rousseau's article 'Musique' with the original one found in Chambers. If for the greater part of the entry, Rousseau simply translated Chambers word for word, he nevertheless made three significant editorial decisions. First, he deleted a significant passage on what Plato had to say about divine and celestial music. ${ }^{54}$ Second, he disregarded a long passage that discussed the respective merits of ancient and modern music. And finally, he decided to add a passage of his own: a lengthy discussion that praises Plato for seeing the close connections between musical and political license, and the connections between the soul and the types of music children listen to. In short, Rousseau deleted almost everything that had to do with (musical) metaphysics and chose to add more extensive reflections on the more concretely 'political' dimension of Plato's treatment of music.

\section{An incomplete Plato}

Rousseau thus separated what Plato saw as intimately and inevitably connected: the sky, the city and the soul. For Plato, the science of harmony and musical contemplation were no less political than a detailed consideration of which instruments children ought to play. In fact, a discussion of one without the other was unthinkable: Plato's concern for the polis was always informed by his more speculative concerns for cosmic order and ontology. While le citoyen de Genève agrees with Plato that the city and the soul cannot be thought of in isolation, he is too much of an Enlightenment figure to see what 'speculative' metaphysics could have to do with this. Contra Diderot and Voltaire, Rousseau did not hesitate to give Plato the label of "divin", but from this we can-

54 For the two entries, see ROC V and appendix 13 of Alain Cernuschi, Penser la musique dans l'Encyclopédie (Paris: Honoré Champion, 2002). 
not infer that Rousseau embraced Plato's metaphysics - as some have done. ${ }^{55}$ For all his praise of Plato, Rousseau never substantially painted Platonic metaphysics in a positive light nor shown much appreciation for the idealism of the kallipolis. Rousseau repeatedly locates the Republic in the "pays des chimères" and in Julie, insists that there is much nonsense about Plato's idea of reincarnation. ${ }^{56}$

What is also remarkably anti-Platonic about Rousseau is his acceptance of doubt, his objection to the esprit de système, and his characterization of the contemplative life as quite pernicious. As he writes in Emile, "Les idées générales et abstraites sont la source des plus grandes erreurs des hommes; jamais le jargon de la métaphysique n'a fait découvrir une seule vérité, et il a rempli la philosophie d'absurdités.... ${ }^{\prime 57}$ Plato would not have gotten along with the Savoyard Vicar - not only because of the latter's conviction that abstract contemplation is inevitably bound with obscurity and futility, but also because the Vicar was convinced of the desirability of accepting a state of doubt. If Plato saw critique and doubt as essential parts of the philosophic pursuit, he did not see them as acceptable end-points. He would have had little patience for the idea that at the end of the day, one simply has to accept certain truths if they 'feel' right and are sincerely one's own. ${ }^{58}$ That Rousseau should be no true Platonist is of course not that surprising given his great concern with practical knowledge and his relative indifference to ontology.

For all his praise of Plato and criticisms of Socrates, Rousseau showed a remarkable kinship with the French Enlightenment. If Mark Hulliung is right to suggest that the philosophes were united in their preference for the vita activa, ${ }^{59}$ Rousseau is, in that respect at least, one of them. Indeed, like many philosophes, Rousseau (wrongly) associated contemplation with a variety of vices that ranged from pride to obscurity, and more importantly, he saw speculative philosophy as antagonistic to political action. As he wrote in his Dialogues, "la vie contemplative dégoute de l'action." ${ }^{\prime \prime 0}$ Platonic contemplation was thus discarded by the philos-

55 For example see Williams, Rousseau's Platonic Enlightenment.

56 Respectively, ROC III, 810; IV, 250; II, 727.

57 ROC IV, 577.

58 ROC I, 1016.

59 Mark Hulliung, The Autocritique of Enlightenment (Cambridge: Harvard University Press, 1994), 78-79.

60 ROC I, 822. 
58 Sophie Bourgault

ophes without a trial - a trial that could have shown the extent to which Plato's ideal philosopher is a friend of the city.

SOPHIE BOURGAULT

University of Ottawa 